\title{
Naming Nature: The Clash Between Instinct and Science
}

Carol Kaesuk Yoon. 2009. W.W. Norton, New York. Pp. 344, index, bibliography, illustrations. \$27.95(cloth). ISBN

9780393-061970.

\author{
Reviewed by E. N. Anderson ${ }^{1}$ \\ Reviewer Address: ${ }^{1}$ Department of Anthropology, University of California, Riverside, Riverside, California 92521
}

Received: November $28^{\text {th }} 2009$

Published: August $31^{\text {st }} 2010$
Volume 1:30-32

(C) 2010 Society of Ethnobiology
This is a pleasant book, a popular introduction to taxonomy. Carol Yoon, a science writer for the New York Times, writes in an easy, popular style. The book tells the story of taxonomic thinking, with a little on traditional systems and the Greeks, a great deal on Linnaeus, and a quick overview of taxonomy since then. Julian Huxley gets at least a mention and Ernst Mayr gets high marks for introducing the biological species concept. She sees Ernst Mayr's introduction of the new Darwinian synthesis to systematics as a major breakthrough, but sees cladistics as the only real scientific taxonomy. Before the cladists, taxonomy was a wasteland, with biologists imposing purely arbitrary views on the world, such as sterile arguments between lumpers and splitters and dry-as-dust museum classifications based on superficial appearances. The situation was saved by cladistics, which allowed first numerical scoring of traits and then proper use of genetic evidence to classify things right-according to biological evolution. Yoon has absorbed the missionary enthusiasm of some cladists.

Her basic thesis is that humans naturally classify the world, and do a fairly good job, but keep coming up with categories like "fish" that are biologically incoherent. "Fish" becomes a theme for the book; she traces the reclassification that makes us now realize that we humans (as well as birds, reptiles, and so on) form a clade with the bony fish, over against the clades of elasmobranch and agnathic fish. She also notes that mushrooms are closer to people than to plants. Eventually, she comes to terms with the folk classification "fish," and realizes that biological relationship is not necessarily the only reason for classifying.

She discusses human information processing limits, such as the difficulty of knowing more than 500-600 things in one domain (p. 142), a point often made by Eugene Hunn (see esp. Hunn 2008). She mentions interesting cases of people with brain trauma that cost them the ability to classify the biological world. They did not lose other classifications-so there does seem to be a specific mental module for biological taxonomizing. She also has very good things to say, toward the end of the book (pp. 272ff), about the need to reverse our current alienation from nature and our loss of knowledge and names.

Unfortunately, as many readers will already realize, her historical picture is a serious oversimplification of the real situation. Popularizations can be pardoned for exaggerating conflicts and "breakthroughs," but in addition Yoon's thin scholarship makes her more detailed accounts less convincing than the broad outline might suggest.

Folk taxonomy is an arcane topic (I have to admit), so it is no surprise that this is the least developed theme in the book. Yoon uses the concept of umwelt to label the natural human tendency to classify nature in particular ways. (The subtitle more forthrightly calls it "instinct.") The umwelt, for her, includes classification systems derived from ordinary experience. She gets the concept from Jakob von Uexküll, but does not cite his deservedly classic work Umwelt und Innenwelt der Tiere (1921), and has apparently gotten the idea from the secondary literature.

The problem is that "umwelt" is a technical philosophical term for the perceived and experienced environment of an individual. Uexküll could speak of the umwelt of a sea urchin or dog because their experienced worlds are reasonably species-general. Humans are not so easily stereotyped. My umwelt is very different from an Inuit's. More to the point, though, a classification system is a cultural representation of a linguistic entity that is derived from interaction of many individuals, each of whom has his or her own umwelt. So, when we study taxonomy, we are actually at least three layers away from the umwelt. Classification systems reflect not only the innate 
perceptual worlds of people, but also their cultural and linguistic worlds, and their immediate needs of the moment. A florist's classification of roses is very different from a botanist's; this difference has nothing to do with a pan-human umwelt and everything to do with the real personal umwelt and with cultural context.

Humans do, however, classify the world with remarkable consistency, as Cecil Brown has repeatedly demonstrated. (Yoon cites Brown, as well as Brent Berlin and Scott Atran.) The form-classes like "fish" and "tree" are worldwide. Yoon is aware of this, but seems not to realize that traditional people are quite aware that there are differences between useful formclass characterizations and classifications based on biological closeness (however calculated). My Chinese fisher friends in Hong Kong used $y u$ "fish" to mean any free-swimming water animal. They knew perfectly well that cuttlefish- "fish" in both English and Chinese-are more like octopi than like carp. They knew that porpoises were "like pigs inside" and acted more like mammals than like ordinary fish. Cuttlefish and porpoises were fish because they swam, not because they belonged together in any other way. "Tree," also, is recognized by most people as a formclass rather than a biological entity; we know that trees can be dwarfed into bushes, and begin life as "herb"like seedlings. A classification system, in short, is about naming things in culturally useful ways. It does reflect innate human classifying tendencies, but it is not a simple reflex of anyone's umwelt. Interestingly, Graham Burnett's Trying Leviathan (2007), which I recently reviewed in this journal, has all this right; Burnett has a real feel for how people classify.

Yoon maintains that Linnaeus more or less singlehandedly created scientific taxonomy. She dismisses earlier efforts, from Aristotle onward, as basically local or folk systems based on that instinctive umwelt. This is less than fair to Aristotle and his student Theophrastus, who had quite good taxonomic sense. It is less fair to later writers from Dioscorides to Maimonides, who really understood the need for commonly understood names, and who defined international nomenclatures, providing full synonymies. They also had some glimmering of biological relationships; Dioscorides grouped like with like when he reasonably could (see Gunther 1934). Maimonides' stunning dictionary of medicines remains one of the great achievements in the history of taxonomy (Maimonides 1979).

Moreover, Linnaeus drew heavily on early modern scientists, notably John Ray. One recent writer (Birk- head 2008) even seems poised to give the self-effacing Ray the credit for breakthroughs that the more selfpromoting Linnaeus claimed and generally receives. (Yoon retells the old stories about Linnaeus' arrogance and his giving ugly weeds the names of his opponents [p. 43]; this latter tale is based on a story that he so served Johann Siegesbeck [p. 131]; but that story is poorly documented in the original sources, and other alleged cases are not documented at all.)

Yoon's claim that taxonomy wallowed in disarray until cladistics and molecular genetics came along, because of excessive dependence on the umwelt (see p. 110), is inaccurate. Cladistics (in its diverse forms) has led to some major breakthroughs, but has not revolutionized taxonomy as much as some cladists would like to believe. Certainly I was taught that "fish" are diverse, and I learned in freshman biology (over 50 years ago!) that I am closer to a carp than a carp is to a shark. The idea that classification should be on the basis of evolutionary relationships was already current in Darwin's day, and developed steadily from then on. The current tendency in taxonomy is to treat the molecular, genetic, and morphological traits as all useful information, and not to rely on any one set.

Lack of deep knowledge of the literature leads Yoon into some strange charges. She blames Mayr and his collaborator Dean Amadon for not bothering to explain why they classified larks as separate from pipits (p. 98), and uses this to maintain her claim that precladistic taxonomy was arbitrary; the actual reason was that Mayr's and Amadon's readers (of whom I was one, when their articles first came out) would have known that anatomical studies over many decades had shown these were different groups, so there was no need to summarize that.

She also seems rather thin on why lumpers and splitters differ, and what the real issues are. The problem is not that people are arbitrary or that they are in the grip of the umwelt; the problem (as Mayr explained extremely clearly in Animal Species and Evolution, 1963) is that nature is not always neat. The taxonomic goal is to "carve nature at the joints" (cf. Berlin 1992), but what if nature lacks joints in some cases?

A good example that Mayr mentioned is the case of the Bullock's and Baltimore orioles (Icterus bullockii and Icterus galbula respectively). These birds meet in the Great Plains and sometimes hybridize, producing viable young. To Mayr, this meant they should be lumpedthey can fairly easily interbreed, therefore are not biologically separate. To others, the rarity of hybrids 
suggests behavioral and ecological barriers. Thus they were different species at first. Then Mayr, Amadon and their contemporaries, imbued with the biological species concept, lumped them as the "Northern Oriole" (I. galbula, the two becoming I. galbula bullockir and I. galbula galbula). Then after the retirement of biologists of Mayr's generation, the orioles were resplit.

This has nothing to do with either the umwelt or arbitrary museum mentalities; it has everything to do with philosophical differences about what to do with genuine borderline cases and empirical reality of the biological world. Such occasionally-hybridizing species are very common in nature, and cladistics does not really make them much easier to deal with. Cladists tend to be splitters, on philosophic grounds; they want to recognize any evolutionarily different clade, even if it might be considered only an incipient one. But that merely kicks the problem down the street a little. There will always be boundary phenomena.

This book is appealing, pleasant, and seductive. Judging from comments on Amazon.com, it is making taxonomy popular and interesting, something that is not always easy to do. This is commendable. Unfortunately, however, the book's limitations are such that it cannot be recommended for class use or reference.

There is a major need for a good, broad-appeal book about this topic. I hope that readers of this review are motivated to write.

\section{References Cited}

Berlin, B. 1992. Ethnobiological Classification. Princeton University Press, Princeton, NJ.

Birkhead, T. 2008. The Wisdom of Birds: An Illustrated History of Ornithology. Bloomsbury, New York .

Burnett, D. G. 2007. Trying Leviathan. Princeton University Press, Princeton, NJ.

Gunther, R. T. 1934. The Greek Herbal of Dioscorides.

Oxford University Press, Oxford .

Maimonides, M. 1979. Moses Maimonides' Glossary of

Drug Names. Tr. F. Rosner. American Philosophical

Society, Philadelphia.

Mayr, E. 1963. Animal Species and Evolution. Harvard University Press, Cambridge, MA.
Uexkúll, Jakob von. 1921. Umwelt und Innenwelt der Tiere. J. Springer, Berlin. 